\title{
Studies on the species of Fanniinae (Diptera: Muscidae) from Japan \\ 1. One new and three newly recorded species of the genus Fannia
}

\author{
Kazumi NiSHIDA* \\ Department of Medical Zoology, Tokyo Medical \& Dental \\ University, Bunkyo-ku, Tokyo 113 \\ (Received: March 20, 1974)
}

\begin{abstract}
In the present paper, Fannia aerea (Zetterstedt), Fannia metallipennis (Zetterstedt) and Fannia spathiophora Malloch are newly recorded. These are Holarctic species, and could be collected in the higher mountains (at about $2,000 \mathrm{~m}$ above sea level) of Honshu in summer. One new species belonging to the minutipalpis subgroup of carbonaria group is described in the present paper. It is very interesting that the allied species are only found in North America.
\end{abstract}

\section{INTRODUCTION}

The studies on Fanniinae is being advanced by many workers, and became easier owing to Hennig's (1955-1964) and Chillcott's (1961) revision. At present time subfamily Fanniinae is considered to include six genera. Fannia R.-D. is main genus and contains about 220 known species. Euryomma Stein contains 9 known species. The other four contain only one or two species, with one each in Piezura Zetterstedt, Xestomyia Stein and Hennigomyia Mihályi, and two in Platycoenosia Strobl. Most of them except Euryomma are occurring in Holarctic region. From Japan two genera, Fannia and Euryomma, are known. One species of the genus Euryomma and 28 species of the genus Fannia were already recorded. It is suspected that some more species belonging to the subfamily Fanniinae could be found from Japan in future. One new and three newly recorded species from Japan are dealt with in this paper.

* 西田和美: 東京医科歯科大学医動物学教室（東京 都文京区湯島 1 丁目 5-45)

\section{Fannia aerea (Zetterstedt, 1845)}

Japanese name: Keshi-hime-iebae

Aricia aerea Zetterstedt, 1845, Dipt. Scand. $4: 1605$.

Homalomyia aerea: Stein, 1895, Berl. Ent. Zeitsch. $40: 70$.

Fannia aerea: Stein, 1907, Kat. Pal. Dipt. $3: 656$.

Anthomyia aerea: Meigen, 1826, Syst. Beschr. 5:157 (misdetermination of Musca aërea Fallén).

Anthomyia aerea: Zetterstedt, 1838, Ins. Lappon. 686 (misdetermination of Musca aërea Fallén).

Homalomyia aeria: Meade, 1897, Descrip. Brit. Antho. 63.

Homalomyia carbonaria: Rondani, 1870, (nec Meigen), Bull. Soc. Ent. Ital. 2 : 324. Homalomyia rondanii Strobl, 1803, Verh. Zool.bot. Ges. Wien. $43: 241$.

Fannia rondanii: Hennig, 1955, Flieg. palae. Reg. 63 b : 79.

Fannia crassipes: Malloch, 1912, Scott. Nat. 179 (condition name for misdetermination).

Type and type locality: Not known. Type in the Zetterstedt's collection at Lund, Sweden. Type locality of rondanii : Piemonte, 
Italy ; type location not known.

o.- Head: Eyes bare. Frontal setae 5 to 7 , sometimes with a few tiny interstitials. Frons very narrow. Frontal vitta linear. Parafacialia bare and very narrow. Parafrontalia bare on upper half. Occipital setae short and regular in length. Postoccipital setae absent. Arista subpubescent. Theca pollinose. Palpi filiform.

Thorax: Ground color black, grayish brown pollinose, and non-vittate. Acr triserial, but sometimes median row incomplete presuturally. Pra 2, posterior one weaker.

Legs : Black, but fore knee reddish brown. Fore tibia with a preapical $d$. Mid tibia with $1 a d, 1$ preapical $d$ and no $p d$; with a short and erect pubescence on apical half. Mid metatarsus with distinct and thorn-like tooth at extreme base. Hind coxa bare on inner posterior margin. Hind femur with a row of $p v$. Hind tibia with $1 a v, 1 a d, 1 d$ and 1 preapical $d$.

Wings: Infuscated. Veins brown. Squamae infuscated, with darker fringe; lower one linear. Halter brown.

Abdomen: Ground color black, with brownish gray pollen. With triangular markings on 2nd, 3rd and 4th tergites, and a median stripe on 5 th tergite.

ㅇ - Unknown.

Length: $\hat{o}: 3.3-3.7 \mathrm{~mm}$.

Records : 7 of $\hat{o}$, Mt. Asama, Nagano, Japan, 25 Jul. 1972 (K. Nishida).

Distribution : Japan (Honshû), Scandinavia, Kurland, Germany, France, England, Scotland, Ireland, Corsica. Hungary and North America.

\section{Fannia metallipennis (Zetterstedt, 1838)}

Japanese name: Haguro-hime-iebae

Anthomyza metallipennis Zetterstedt, 1838, Ins. Lappon. 659.

Homalomyia kowarzi: Verrall, 1892, Ent. Mo. Mag. $28: 149$.

Type and type localiiy: Type in the Zoologiska Institution, Lund, Sweden. Type locality of kowarzi: England, between Matlock and Matlock Bath; type in Collin's collection, Newmarket, England.

o. - Head: Eyes bare. Frontal setae 10 to 14 , with a few fine and short interstitials.
Frontal vitta distinctly throughout. Ground color of parafacialia, parafrontalia and frontal vitta black. From certain angles, parafacialia and parafrontalia silvery gray pollinose. Occipital setae short and becoming longer toward vertex, but the setae near vertex very long. Postoccipital setae in one irregular row. Arista subpubescent. Palpi filiform. Theca black subshining.

Thorax: Ground color black. Brownish gray pollinose. Non-vittate. Prest acr biserial, post acr triserial. Pra 2.

Legs: Black, but knees yellowish brown. Fore tibia with a preapical $d$. Mid tibia with $1 a d, 2-3 p d$ and 1 preapical $d$; with a ventral mat of erect and long hairs on basal two-thirds. Mid metatarsus with inconspicuous crest at the base ventrally. Hind coxa bare on inner posterior margin. Hind femur on postventral surface weakly swollen preapically, and with a tuft of numerous fine hairs on that portion. Hind tibia with 2-3 av, $1 d, 1 \mathrm{ad}$ and 1 preapical $d$.

Wings: Infuscated. Veins brown. Squamae infuscated, with darker fringe; lower one projecting. Halter yellowish brown.

Abdomen: Ground color black, brownish gray pollinose. With a triangular markings on 2nd, 3rd and 4th tergites, and a median stripe on 5 th tergite.

우 - Unknown.

Length: $\quad$ o : $4.8-5.4 \mathrm{~mm}$.

Records: $5 \hat{o} \hat{o}$, Mt. Asama, Nagano, Japan, 25 Jul. 1972 (K. Nishida), 12 o $\hat{o}$, Mt. Myôkô, Niigata, Japan, 16-18 Jul. 1973 (K. Nishida).

Distribution: Japan (Honshû), England, South Sweden, Germany, Austria and North America.

\section{Fannia spathiophora Malloch, 1918}

Japanese name: Kagite-hime-iebae

Fannia spathiophora Malloch, 1918, Trans. Amer. Ent. Soc. $44: 293$.

Type and type locality: Gold Rock, Ontario. Type in the Illinois Natural History Survey collection.

o. Head: Eyes bare. Frons very narrow. Frontal setae about 6 , with a few fine interstitials. Parafrontalia contiguous medially. Parafacialia very narrow and bare. Occipital 
setae short and regular in length, but longer near vertex. Postoccipital setae absent. Theca glossy, slender. Palpi weakly spatulated.

Thorax: Ground color black. Brownish gray pollinose. Non-vittate. Prest acr biserial, post acr triserial. Pra 2.

Legs : Black, but fore knee reddish yellow. Fore tibia with 6-7 of long and fine $p r$ on apical two-thirds, and a preapical $d$. Fore metatarsus with 1 or 2 of fine and long ventral setulae at extreme base. Mid tibia with $1 \mathrm{ad}$, no $p d$; about 7 long apical ventral setae curled over at the tips; apical $v$ and apical ad strong. Mid metatarsus with long ventral crest at extreme base. Hind coxa bare on inner posterior margin. Hing femur with one strong $p v$; longer $p v$ on basal half, preapical two of them strong. Hind tibia with $1 a v, 1$ weak $a d, 1 d$ and 1 preapical $d$.

Wings: Slightly infuscated. Veins brown, paler basad. Squamae pale yellow.

Abdomen: Ground color black. Brownish gray pollinose. With a triangular markings on 2nd, 3rd and 4th tergites, and an obscure stripe on 5 th tergite.

ㅇ. Unknown.

Length: $\hat{o}$ : about $4.2 \mathrm{~mm}$.

Record: 1\}, Mt. Asama, Nagano, Japan, 25 Jul. 1972 (S. Shinonaga).

Distribution: Japan (Honshû), Sweden, Finland, Germany and North America.

\section{Fannia japonica sp. .nov.}

Japanese name: Yamato-hime-iebae

ô.- Head: Frons not so much arched, at narrowest point about twice as wide as diameter of anterior ocellus. Eyes bare, sometimes with a few short hairs vestigially; about twice as deep as long. Ocellars fine and long, directed forward. Occipital setae short and regular in length, but longer near vertex. Postoccipital setae absent on dorsal third. Ground color of parafacialia, parafrontalia, and frontal vitta black. From certain angles, parafacialia and parafrontalia silvery pollinose, and frontal vitta light brownish gray pollinose. Frontal setae 9 to 11, sometimes with a few short interstitials. Parafrontalia narrow and almost contiguous. Parafacialia bare, narrow. Antennae black, 2nd segment with a long seta among a few tiny setulae, 3rd segment about 2.5 times as long as wide. Arista subpubescent, short, about twice the length of 3rd antennal segment, conspicuously thickened basal fifth to sixth. Proboscis black, theca glossy and swollen, black but sometimes reddish brown. Palpi black, shorter than thecal length, spatulated, with a few long setulae at apex.

Thorax: Ground color black, non-vittate, thinly covered with grayish brown pollen on dorsum. Acr evenly biserial throughout, setae strong. $D c 2+3 ; h 2 ; p h 2$, with a few setulae around them; ia 2 ; sa 1 ; pra 1, long; $p a 2$. Ancillary setulae on dorsum very sparse. Propleural depression bare; with 2 setae on ridge beneath, the posterior one stronger. One strong prostigmatal seta, with a few fine and long setulae around it. Stpl 1:1, with a number of fine and long setulae between them, without ventral spine between fore and mid coxae. Scutellum black, thinly covered with grayish brown pollen, also with pairs of strong lateral and apical scutellar setae. Ancillary setulae on scutum very sparsely present. Bare on side and beneath.

Legs: Black, but fore knee yellowish brown. Fore femur with full rows of $p v, p$ and $p d ; p$ curled over at the tips; without well developed $a v$. Fore tibia with a preapical $d$. Mid coxa without ventral spine. Mid femur uniform width on basal twothirds and then gradually becoming thinner on apical third; with 6-8 long and widespaced $a v$ on basal two-thirds and then 10-12 short closely situated $a v$ in a comb on apical third; with a row of long $p$, curled over at the tips, 3-4 of preapical setae strong; $p v$ becoming shorter and double in rows on apical two-thirds. Mid tibia with the ventral mat of the hairs of which length about equal to tibial diameter; with $2 \mathrm{ad}, 2 p d$ and 1 preapical $d$. Mid metatarsus without ventral crest at the base. Hind coxa hairy on inner posterior margin. Hind femur with a row of $a v, 2-3 a d, 1$ preapical $d$ and 1 preapical $p d$; posteroventral surface setulose except for apical third. Hind tibia with 1-2 av, 1 $-2 a d, 1 d$ and 1 preapical $d$.

Wings : Somewhat smoky. Veins of wing brown, becoming paler based. Squamae 
pale brown to yellow, with dark fringe, lower one projecting. Halter pale to yellowish brown.

Abdomen: Ground color black, gray or bluish gray pollinose. With a triangular markings on 2nd, 3rd and 4th tergites, and a median stripe on 5 th tergite. Fifth sternite broader than long, with a number of spinose setae. Cercal plate oval in caudo-ventral aspect, not elongated, with a median button and two slender sublateral hooks. Surstylus strongly expanding medially. Bacilliform process slender and short, scarcely spiralled (Figs. 1-3).

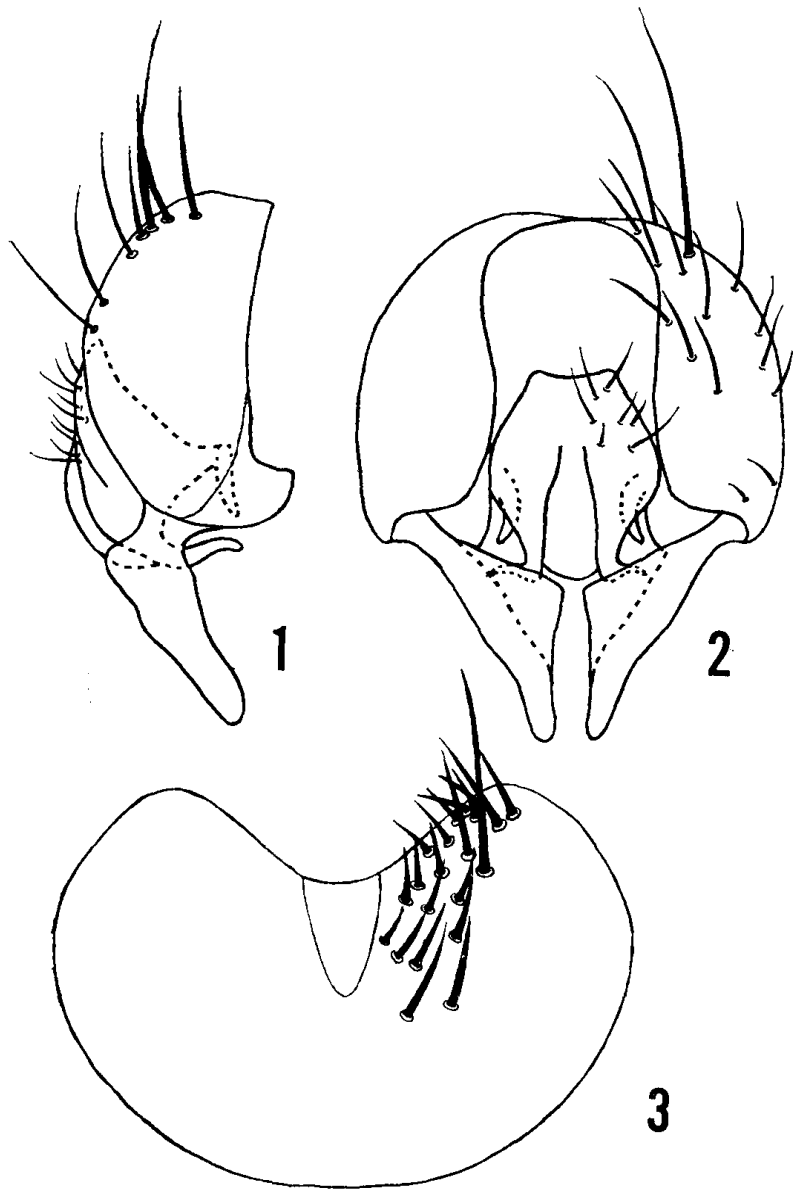

Figs. 1-3 Fannia japonica sp. nov. (Paratype): 1. Hypopygium, lateral aspect; 2. ditto, caudo-ventral aspect; 3 . 5 th sternite.

우- Unknown.

Length : ô : $4.0-4.5 \mathrm{~mm}$.

Holotype: $\$$. Mt. Shirouma, Nagano, 13 Aug. 1972 (K. Nishida). Paratypes : $27 \hat{\delta} \hat{o}$, the same data as holotype. Two male paratypes are presented to the British Museum, London, and Canadian National Collection of Insects, Ottawa. The other specimens including holotype are preserved in the National Science Museum, Tokyo.

Distribution: Japan (Rishiri Is., Hokkaidô, Honshû, Kyûshû and Tsushima Is.).

Remarks and relationship: This species seems to be widely distributed in Japan, and can be commonly found on the paths in lower hills in spring and in higher mountains in summer in Honshu, and in the garden of farm-house in Tsushima Island in May. A small number of spring form was collected in planes and hills in April, which somewhat differs from the type series in the following characters: eyes with distinct but sparse hairs, frons strongly arched, parafacialia and parafrontalia wide, frontal setae 6-8, wings clear, abdomen rather wider, median button of cercal plate somewhat larger. The differences of external characters of the spring form are hardly distinguished from those of the type series. The present new species belongs to the minutipalpis subgroup of the carbonaria group, and is very closely allied to two Nearctic species, Fannia brevipalpis Chillcott and Fannia trigonifera Chillcott. These two species are rather similar to the spring form than the type series.

Fannia brevipalpis differs from $F$. japonica sp. nov. by the following respects: parafacialia and parafrontalia wide, mid femur with several rows of $a v$ on distal one-fourth and with the break preapically following them, sublateral process of cercal plate wider, surstylus weakly expanding, abdominal vitta linear.

Fannia trigonifera is distinguished from $F$. japonica sp. nov. by the following characters: genae yellowish-brown pollinose, mid tibia with 1-2 pd, surstylus hardly expanding medially, the median button of cercal plate slender.

\section{ACKNOWLEDGEMENTS}

The author wishes to express his sincere thanks to Mr. Adrian C. Pont of the Department of Entomology, British Museum (Natural History), for giving him the valuable suggestion about Fannia japonica sp. nov., and to Prof. R. Kano of the Department of Medical Zoology, Tokyo Medical \& Dental University, for reading the 
manuscript. He is also grateful to Dr. S. Shinonaga of the Department of Medical Zoology, Tokyo Medical \& Dental University and Mr. H. Kurahashi of the Department of Medical Entomology, National Institute of Health, Tokyo, for their kindness in offering the valuable specimens, and to Dr. J. R. Vockeroth of the Entomology Research Institute, Canada Department of Agriculture, Ottawa, for his kindness in providing the specimens of Fannia brevipalpis.

\section{REFERENCES}

Assis Fonseca, E. C. M. (1968) : Diptera Cyclorrhapha Calyptrata. Section (b) Muscidae, in Handbooks for the Identification of British Insects, London, 119 pp., 16 figs., 6 plates.

Chillcott, J. G. (1961): A revision of the Nearctic species of Fanniinae(Diptera: Muscidae). Canad. Ent. 92, Suppl. 14:5-295, 289 figs., 61 maps, 1 table.

Hennig, W. (1955-1964) : Muscidae, in Lindner,
Die Fliegen der Palaearktischen Region $63 \mathrm{~b}$ : 1-1110, 429 figs., 33 plates.

$$
\begin{gathered}
\text { 摘 要 } \\
\text { 日本産ヒメイエバェ亜科に関する研究. I } \\
\text { ヒメイエバェ属の1新種，および } \\
3 \text { 未記録種 }
\end{gathered}
$$

現在まで日本で報告されたヒメイエバエ亜科（Fanniinae)に属する種数は，ヒメイエバエ属 (Genus Fannia) 28 種, ニセヒメイエバエ属 (Genus Euryomma) 1 種である.

本論文では，そ礼方汇加えて日本未記録種，Fannia aerea, F. metallipennis, $F$. spathiophora, と 1 新種を 記録した. 末記録の 3 種はす心゙て夏季に本州の山岳地帯 （海抜約 2,000メートル付近）で採集したものである.

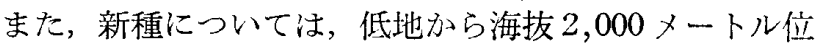
までの山岳地帯で 4 〜月にかけて採集でき，春および 夏季それぞれの採集品の間には外形的に多少の変異はあ るが，交尾器について性ほ上んど変異がない。 